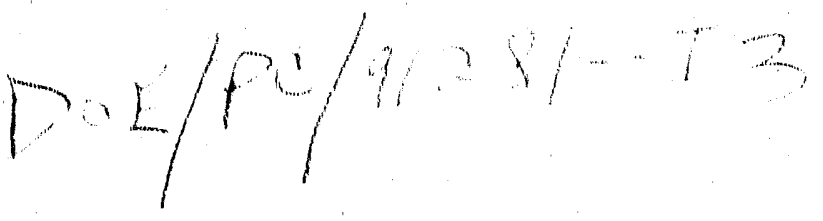

\title{
LOW SEVERITY COAL LIQUEFACTION PROMOTED BY CYCLIC OLEFINS
}

DOE/PC/91281-.-T3

Grant No: DE-FG22-91PC-91281

DE92 040657

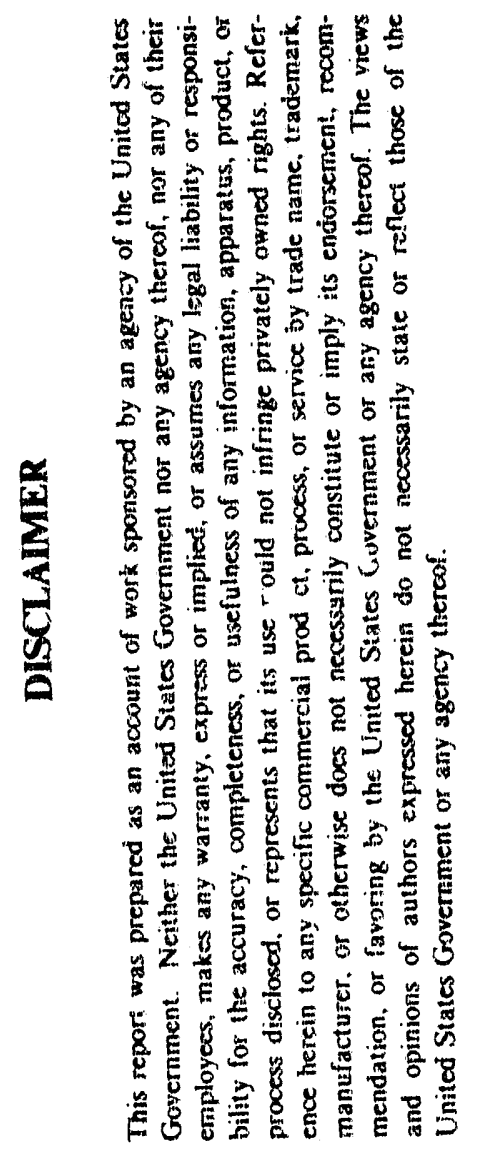

Quarterly Report

April - June 1992

Christine W. Curtis

Chen : at Fingucering Department

Auburn University, AL 368-99-5127 


\section{Acknowledgements}

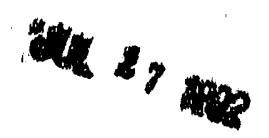

The experimental work of An Ping Huang is gratefully acknowledged. The technical support of Frank Bowers and Joe Aderholdt is appreciated.

NHIU.COAL.LIQ 


\section{Table of Contents}

Page

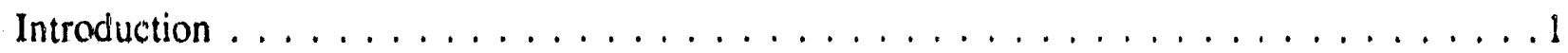

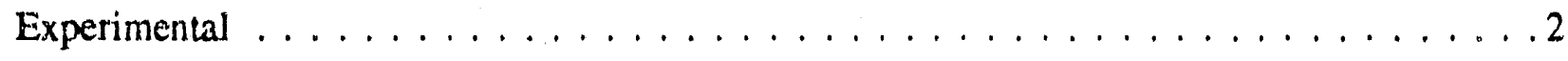

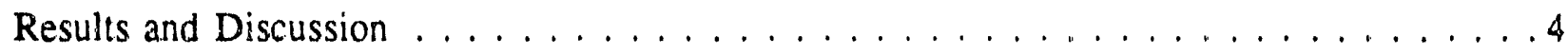

Parametric Evaluations $\ldots \ldots \ldots \ldots \ldots \ldots \ldots \ldots$

Anthracene Hydrogenation Under Thermal and Catalytic Conditions . . . . . . . 5

Hexahydroanthracene Reactions Under Thermal and Catalytic

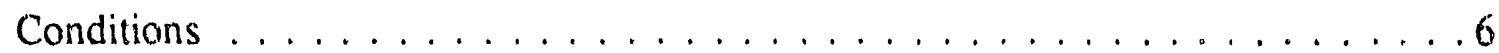

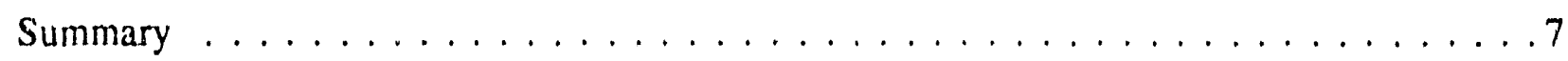

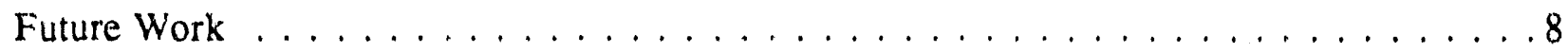

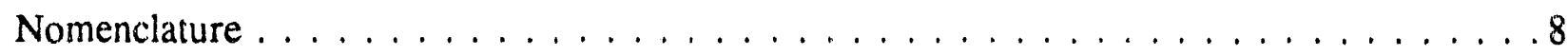

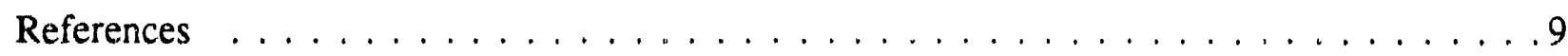




\section{LOW SEVERITY COAL LIQUEFACTION PROMOTED BY CYCLIC OLEFINS}

\section{Introduction}

Low severity coal liquefaction allows for solubilization of coal with reduced gas make. These lower severity conditions may result in some selective bond rupture. However, usually at low severity conditions, the amount of coal solubilization is much lower than what is normally obtained at higher severity conditions. Promotion of coal solubilization through hydrogen transfer using highly active and effective hydrogen donors is the objective of this study.

The highly effective donors being tested are cyclic olefins. Representative cyclic olefins are isotetralin, which is $1,4,5,8$-tetrahydronaphthalene, and $1,4,5,8,9,10$-hexahydroanthracene. These compounds are hydroaromatics without aromatic rings and have been shown to be highly effective donors (Bedell and Curtis, 1991). Some recent studies have compared the ability of isotetralin to release hydrogen at $380^{\circ} \mathrm{C}$ in both nitrogen and hydrogen atmospheres to that of tetralin. Likewise, at $380^{\circ} \mathrm{C}$ the ability of hexahydroanthracene to release hydrogen in nitrogen and hydrogen atmospheres was compared to that of dihydroanthracene. At equivalent reaction conditions and in the presence of anthracene as a hydrogen acceptor, isotetralin released more than 200 times as much hydrogen as tetralin and hexahydroanthracene released 18 to 25 times as much as dihydroanthracene (Wang, 1992).

The objective of the work performed in this siudy during this quarter was to evaluate reaction parameters for low severity liquefaction reactions using the cyclic olefin, hexahydroanthracene, and the aromatic, anthracene. These model compouncis were reacted under a variety of conditions to evaluate their reactivity without coal. The reactions were 
performed under both thermal and catalytic conditions. Finely divided catalysts from different molybdenum precursors were used to determine their activity in promoting hydrogenation and hydrogen transfer at low severity conditions. The catalysts used were Molyvan L, sulfurized oxymolybdenum dithiocarbamate, molybdenum naphthenate, and Molyvan 822 , organo molybdenum dithiocarbamate.

\section{Experimental}

A parametric evaluation of the reactivity of two model systems, anthracene (ANT) and hexahydroanthracene $(\mathrm{HH} /$ ) was performed under both thermal and catalytic reaction conditions. Both ANT (99\% purity) and HHA (97\% purity) were obtained from Aldrich Chemical Co. The solvent used in the reaction was hexadecane (99\% purity) also from Adlrich Chemical Company. Molyvan L and Molyvan 822 were obtained from Vanderbilt Company and molybdenum naphthenate was obtained from Shepherd Chemical Company.

Low severity reaction conditions were employed. A parametric evaluation of ANT hydrogenation was undertaken with Molyvan L and Molyvan 822 as catalyst precursors. The reaction conditions were reaction temperatures of 300,350 , and $400^{\circ} \mathrm{C}$ at hydrogen pressures of 500 and $1000 \mathrm{psig}$ introduced at ambient temperature. The catalyst precursors were introduced at $1500 \mathrm{ppm}$ of Mo and tested with and without sulfur. The sulfur level was a 3:1 $S$ to Mo stoichiometric ratio. ANT was introduced at $2 \mathrm{wt} \%$ in a hexadecant solution to the stainless steel tubular reactor of $\sim 20 \mathrm{~cm}^{3}$. The reactions were conducted for 30 minutes and were well-agitated. 
The reaction conditions for the ANT hydrogenation reactions were reaction temperatures of 300,350 , and $400^{\circ} \mathrm{C}$ and a hydrogen pressure of $500 \mathrm{psig}$ introduced at ambient temperature. The reactions were performed for 30 minutes in a $-20 \mathrm{~cm}^{3}$ stainless steel tubular reactor. ANT was introduced at $2 \mathrm{wt} \%$ in hexadecane; a $4 \mathrm{~g}$ total charge of liquid was introduced into the reactor. The catalysts precursors used were Molyvan L, Molyvan 822, and Mo naphthenate. All of the catalyst precursors were introduced at a level of $500 \mathrm{ppm}$ of Mo. Molyvan 822 and Mo naphthenate were reacted in the presence of sulfur where sulfur was added at a $3: 1 \mathrm{~S}$ to Mo stoichiometric ratio. Molyvan $\mathrm{L}$ was reacted in the absence of sulfur. The reaction was conducted for 30 minutes and the reactor was well-agitated. HHA was reacted under similar conditions as ANT except that the temperature range was shifted lower. The reaction temperatures used were 250,300 , and $350^{\circ} \mathrm{C}$.

The product analysis was conducted using a Varian 3700 gas chromatograph equipped with a Supelco DB5 column, spetumless injector and flame ionization detector. The products were qualitatively identified by spiking with authentic compounds and by analyzing with GC mass spectrometry using a VG70 EHF GC mass spectrometer. Quantitative analysis of the products were achieved using the internal standard method with $\mathrm{p}$-xylene as the internal standard.

The following term, percent hydrogenation (\% HYD), is defined to assist in comparing the results from a number of different reactions. Percent hydrogenation is the number of moles of hydrogen required to produce the liquid reaction prosiks is a percentage of the moles of hydrogen required to achieve the most hydrogenated product. For anthracene, the most hydrogenated product was considered to be perhydroanthracene. 


\section{Results and Discussion}

The objective of the experiments performed this quarter was to evaluate the reactivity of the model systems at low severity conditions and to determine the activity of the catalyst precursors at those conditions. The experiments performed involved a parametric evaluation of the activity of two catalyst precursors with ANT and an examination of the thermal and catalytic hydrogenation of ANT and HHA under low severity conditions. Next quarter, these reactions will be performed with coal to evaluate the effect of hydrogen tiansfer from the cyclic olefin HHA on coal conversion in comparison to an aromatic ANT under thermal and catalytic low severity conditions.

Parametric Evaluations. The parametric evaluations of ANT hydrogenation using catalyst precursors, Molyvan $\mathrm{L}$ and Molyvan 822, are presented in Tables 1 and 2. The purpose of this evaluation was to determine if the presence of sulfur in the reactor helped or hindered the activity of the catalyst precursor for ANT hydrogenation. Previous experiments involving naphthalene indicated that sulfur present in the reaction with Molyvan L was detrimental to naphthalene hydrogenation (January-March 1992 Quarterly Report).

The data in Table 1 present the activity of Molyvan L for ANT hydrogenation with and without sulfur. The loading of the catalyst was $1500 \mathrm{ppm}$ of Mo. In the reactions without sulfur, two partially hydrogenated anthracene products were observed, dihydroanthracene (DHA) and tetrahydroanthracent (T:A). Al the higher temperature of $400^{\circ} \mathrm{C}$, more THA was produced than at the lower temperatures of 350 and $300^{\circ} \mathrm{C}$. For each temperature, the amount of ANT hydrogenation was slightly higher for the higher hydrogen fressure of 1000 psi than for the lower pressure of $500 \mathrm{psi}$. The $\%$ HYD did not vary much from the most severe condition at 
$400^{\circ} \mathrm{C}$ and 1000 psi where $15.2 \%$ HYD was obtained compared to the least severe condition of $300^{\circ} \mathrm{C}$ and 500 psi which yielded $13.6 \% \mathrm{HY}$.

The Molyvan L reactions with sulfur yielded less \% HYD of ANT than did the reactions without sulfur. Only the $400^{\circ} \mathrm{C}$ reaction produced any THA; the lower temperature reactions only produced DHA as a product. The influence of the sulfur seemed particularly evident at the lowest severity conditions where the conversion of ANT was only 40 to $50 \%$, depending on the amount of hydrogen present. The range for the \% HYD from the highest to the lowest severity condition was much greater than in the reactions without sulfur.

The hydrogenation of ANT with Molyvan 822 is presented in Table 2. In these reactions, the effect of sulfur, temperature and hydrogen pressure on ANT hydrogenation was evaluated. The amount of hydrogenation observed with Molyvan 822 was considerably more than that observed with Molyvan L. At $400^{\circ} \mathrm{C}$, the hydrogenated products obtained were THA, $\mathrm{HHA}$, and octahydroanthracene $(\mathrm{OHA})$; at $350^{\circ} \mathrm{C}$, the products were DHA, THA, and OHA; and at $300^{\circ} \mathrm{C}$ only DHA was produced. The \% HYD of ANT with Molyvan 822 was similar with and without sulfur, although the activity in terms of \% HYD of ANT with Molyvan 822 without sulfur at $350^{\circ} \mathrm{C}$ was considerably less than the corresponding reaction with sulfur. Temperature seemed to have the most effect on ANT hydrogenation with Molyvan 822: the highest temperature of $400^{\circ} \mathrm{C}$ resulted in substantially more hydrogenation of ANT than did the $10 w^{\prime}$ st temperature of $300^{\circ} \mathrm{C}$. Hydrogen pressure had only a slight effect on $\% \mathrm{HYO}$ with the effect being more apparent at higher temperature.

Anthracene Hydrogenation Under Therma! and Catalytic Conditions. ANT hydrogenation under four conditions was examined and is shown in Table 3. The conditions 
were thermal reaction with no catalyst, catalytic reaction with Molyvan $\mathrm{L}$ without sulfur, catalytic reactions with Molyvan 822 with sulfur, and Mo naphthenate with sulfur. The conditions were selected from the parametric evaluation. The temperature range was 300 to $400^{\circ} \mathrm{C}$, the hydrogen pressure was $500 \mathrm{psi}$ introduced at ambient temperature and the reaction time was 30 minutes.

The thermal reactions only hydrogenated AN'T at $400^{\circ} \mathrm{C}$; at lower temperatures ANT did not react. The product at $400^{\circ} \mathrm{C}$ was DHA. The catalytic reactions produced substantial differences in their reactivity. At $400^{\circ} \mathrm{C}$ Molyvan 822 and Mo naphthenate with sulfur both hydrogenated ANT to DHA, THA, and OHA, yielding \% HYD of 28 to $30 \%$. The primary product was THA. By contrast, Molyvan L without sulfur gave $\sim 14 \%$ HYD with DHA as the primary product and THA as the secondary one. At $350^{\circ} \mathrm{C}$, all three catalyst precursors had similar activity for promoting ANT hydrogenation yielding DHA as the only hydrogenated product with the \% HYD ranging from nearly 13 to $14.3 \%$. At $300^{\circ} \mathrm{C}$, differences were again observed in the activities of the catalyst precursors with Molyvan 822 being the most active at 12.5\% HYD, Mo naphthenate being intermediate at $8.1 \% \mathrm{HYD}$ and Molyvan L least active at 6\% HYD.

Hexahydroanthracene Reactions Under Thermal and Catalytic Conditions. HHA was reacted thermally and catalytically with the same catalyst precursors and conditions as the ANT reactions except that the temperature range was between 250 and $350^{\circ} \mathrm{C}$. ine results from these reactions are given in Table 4. Under thermal conditions, the amount of hydrogen released from HHA was dependent upon the reaction temperature. Only $8 \%$ conversion of HHA occurred at $250^{\circ} \mathrm{C}$ while slightly more than $75 \%$ was converted at $350^{\circ} \mathrm{C}$. The products obtained were 
DHA and OHA at 300 and $350^{\circ} \mathrm{C}$ while only $\mathrm{OHA}$ was produced at $250^{\circ} \mathrm{C}$.

The three catalysts had different activities for hydrogenating HHA. Molyvan L converted 55 to $61 \%$ of HHA to OHA, but no dehydrogenation products were observed. Although the amount of conversion varied somewhat for the three reaction temperatures, temperature did not have a substantial effect on the activity of Molyvan L. More OHA was produced at each temperature compared to the corresponding thermal reaction. Both Molyvan 822 and Mo naphthenate yielded some dehydrogenation products: DHA at 350 and $300^{\circ} \mathrm{C}$ and DHA and ANT at $250^{\circ} \mathrm{C}$. Conversion of HHA was between 55 and $62 \%$ at the three temperatures with Molyvan 822 and between 55 and $71 \%$ with Mo naphthenate. The highest conversion for Molyvan 822 was observed at $300^{\circ} \mathrm{C}$ while that for Mo naphthenate was at $250^{\circ} \mathrm{C}$.

\section{Summary}

The activity of the catalyst precursors was dependent upon their structure and their sensitivity to sulfur. Molyvan L was more active in the absence of sulfur while Molyvan 822 and Mo naphthenate were more active with sulfur.

At higher reaction temperature, anthracene converted more to hydrogenated products than at lower temperatures. Under equivalent temperature conditions, Molyvan 822 and Mo naphthenate both converted more anthracene than did Molyvan L. Likewise higher hydrogen pressures resulted in higher conversion of anthacene. The activity of both Molyvan $\mathrm{L}$ and Molyvan 822 were similarly affe ;ted by hydrogen pressure. The loading level of the catalyst precursor affected the rate of reaction, with the higher loading resulting in higher conversion for the given reaction time of $30 \mathrm{~min}$. The increased catalyst loading affected the reaction system. 
with Molyvan 822 more at higher reaction temperature than at lower, while Molyvan $\mathrm{L}$ was affected oppositely.

Hexahydroanthracene showed more reactivity thermally than did anthracene. Hexahydroanthracene readily gave up its hydrogen particularly at higher reaction temperatures. The reactivity of hexahydroanthracene varied with catalyst precursor and temperature.

\section{Future Work}

Reactions will be performed with anthracene and coal and with hexahydroanthracene and coal during the nexi quarter at these same low severity conditions. The ability of hexahydroanthracene to transfer hydrogen to coal at these lower temperatures and pressures will be evaluated in terms of coal conversion and product fractionation. The coal conversion and amount of solvent fractionated products will be compared between the thermal and catalytic systems using anthracene and hexahydroanthracene as nondonor and donor solvents, respectively.

\section{Nomenclature}

$$
\begin{aligned}
& \text { ANT }=\text { anthracene } \\
& \text { DHA }=\text { dihydroanthracene } \\
& \text { THA }=\text { tetrahydroanthracene } \\
& \text { HHA }=\text { hexaitydroanthracene } \\
& \text { OHA }=\text { octahydroanthracene }
\end{aligned}
$$

Mo naphthenate $=$ molybdenum naphthenate 


\section{References}

Wang, S.L. Master's Thesis, Auburn University, 1992.

C.W. "Low Severity Coal Liquefaction Promoted by Cyclic Olefins," Quarterly Report, January-March 1992.

Bedell, M.W. and Curtis, C.W. Energy and Fuels, 5, 469, 1991. 
Table 1. Anthracene Hydrogenation Using Molyvan L

\begin{tabular}{|c|c|c|c|c|c|c|c|}
\hline \multicolumn{3}{|c|}{ Reaction Conditions } & \multicolumn{5}{|c|}{ Product Distribution (wt \%) } \\
\hline Cutalyst & $\begin{array}{l}\text { Temperg- } \\
\text { ture } \\
\left({ }^{\circ} \mathrm{C}\right)\end{array}$ & $\begin{array}{c}\text { Pressure } \\
\text { (psi) }\end{array}$ & ANT & DIIA & THA & IIIIA & $\%$ IIYD \\
\hline $\begin{array}{l}\text { Molyvan L } \\
\text { (1500 ppm) } \\
\text { Without } \\
\text { Sulfur }\end{array}$ & $\begin{array}{l}400 \\
400 \\
350 \\
350 \\
300 \\
300\end{array}$ & $\begin{array}{r}1000 \\
500 \\
1000 \\
500 \\
1000 \\
500\end{array}$ & $\begin{array}{c}8.01 \pm 0.76 \\
13.80 \pm 0.15 \\
0 \pm 0 \\
9.12 \pm 1.26 \\
0 \pm 0 \\
6.99 \pm 0.31\end{array}$ & $\begin{array}{l}77.38 \pm 0.89 \\
75.43 \pm 1.36 \\
95.57 \pm 0.17 \\
87.22 \pm 0.78 \\
100.0 \pm 0.0 \\
90.39 \pm 0.47\end{array}$ & $\begin{array}{c}14.61 \pm 0.49 \\
10.77 \pm 1.36 \\
443 \pm 0.17 \\
3.66 \pm 0.53 \\
0 \pm 0 \\
2.62 \pm 0.32\end{array}$ & $\begin{array}{l}0 \pm 0 \\
0 \pm 0 \\
0 \pm 0 \\
0 \pm 0 \\
0 \pm 0 \\
0 \pm 0\end{array}$ & $\begin{array}{l}15.2 \\
13.8 \\
14.9 \\
13.5 \\
14.3 \\
13.6\end{array}$ \\
\hline $\begin{array}{l}\text { Molyrun L } \\
\text { (1500 ppm) } \\
\text { With } \\
\text { Sulfur }\end{array}$ & $\begin{array}{l}400 \\
400 \\
350 \\
350 \\
300 \\
300\end{array}$ & $\begin{array}{r}1000 \\
500 \\
1000 \\
506 \\
1000 \\
500\end{array}$ & $\begin{array}{c}8.54 \pm 0.63 \\
17.30 \pm 1.57 \\
21.41 \pm 2.48 \\
41.58 \pm j .16 \\
47.41 \pm 1.89 \\
58.61 \pm 1.78\end{array}$ & $\begin{array}{l}82.7 \% \pm 0.30 \\
75.62 \pm 1.64 \\
78.59 \pm 2.26 \\
58.42 \pm 1.16 \\
52.59 \pm 1.89 \\
41.39 \pm 1.78\end{array}$ & $\begin{array}{c}8.68 \pm 0.48 \\
7.08 \pm 0.24 \\
0 \pm 0 \\
0 \pm 0 \\
0 \pm 0 \\
0 \pm 0\end{array}$ & $\begin{array}{l}0 \pm 0 \\
0 \pm 0 \\
0 \pm 0 \\
0 \pm 0 \\
0 \pm 0 \\
0 \pm 0\end{array}$ & $\begin{array}{r}14.3 \\
12.8 \\
11.2 \\
8.3 \\
7.5 \\
5.9\end{array}$ \\
\hline
\end{tabular}

Table 2. Anthracene Hydrogenation Using Molyvan 822

\begin{tabular}{|c|c|c|c|c|c|c|c|}
\hline \multicolumn{3}{|c|}{ Reaction Conditions } & \multicolumn{5}{|c|}{ Product Distribution (wt $\%$ ) } \\
\hline Catalyst & $\begin{array}{c}\text { Teinperan } \\
\text { ture } \\
\left({ }^{\circ} \mathrm{C}\right)\end{array}$ & $\begin{array}{l}\text { Pressure } \\
\text { (psi) }\end{array}$ & DIIA & THA & IIIIA & OIIA & \% IKXD \\
\hline $\begin{array}{l}\text { Molyvan L } \\
\text { (1500 ppm) } \\
\text { Without } \\
\text { Sulfur }\end{array}$ & $\begin{array}{l}400 \\
400 \\
350 \\
350 \\
300 \\
300\end{array}$ & $\begin{array}{r}1000 \\
500 \\
1000 \\
500 \\
1000 \\
500 \\
\end{array}$ & $\begin{array}{c}0 \pm 0 \\
0 \pm 0 \\
54.67 \pm 1.74 \\
48.11 \pm 2.49 \\
100.0 \pm 0 \\
100.0 \pm 0\end{array}$ & $\begin{array}{c}9.26 \pm 0.66 \\
43.63 \pm 1.38 \\
31.67 \pm 1.37 \\
42.39 \pm 1.68 \\
0 \pm 0 \\
0 \pm 0\end{array}$ & $\begin{array}{c}32.23 \pm 1.55 \\
13.83 \pm 0.42 \\
0 \pm 0 \\
0 \pm 0 \\
0 \pm 0 \\
0 \pm 0\end{array}$ & $\begin{array}{c}58.51 \pm 4.41 \\
42.54 \pm 1.24 \\
13.66 \pm 0.37 \\
9.50 \pm 0.8 .5 \\
0 \pm 0 \\
0 \pm 0\end{array}$ & $\begin{array}{l}49.9 \\
42.6 \\
24.5 \\
24.3 \\
14.3 \\
14.3\end{array}$ \\
\hline $\begin{array}{l}\text { Molyvan L } \\
\text { (1500 ppm) } \\
\text { With } \\
\text { Sulfur }\end{array}$ & $\begin{array}{l}400 \\
400 \\
350 \\
350 \\
300 \\
300\end{array}$ & $\begin{array}{r}1000 \\
500 \\
1000 \\
500 \\
1000 \\
500\end{array}$ & $\begin{array}{c}0 \pm 0 \\
0 \pm 0 \\
28.43 \pm 0.49 \\
23.58 \pm 0.79 \\
100.0 \pm 0 \\
100.0 \pm 0\end{array}$ & $\begin{array}{c}10.46 \pm 2.26 \\
33.14 \pm 1.05 \\
31.85 \pm 0.67 \\
50.45 \pm 1.26 \\
0 \pm 0 \\
0 \pm 0\end{array}$ & $\begin{array}{c}28.83 \pm 5.49 \\
14.32 \pm 0.79 \\
0 \pm 0 \\
0 \pm 0 \\
0 \pm 0 \\
0 \pm 0\end{array}$ & $\begin{array}{c}60.71 \pm 3.47 \\
52.62 \pm 0.38 \\
39.72 \pm 1.08 \\
25.97 \pm 2.03 \\
0 \pm 0 \\
0 \pm 0\end{array}$ & $\begin{array}{l}50.0 \\
45.5 \\
35.6 \\
32.4 \\
14.3 \\
14.3\end{array}$ \\
\hline
\end{tabular}

ANT = Anlhracene

DHA $=$ Dihydroanthracene

THA = Tetrahydroanthracene

HHD = Hexahydroanthracene

$O H A=$ Octahydrounthracene

Reaction Conditions:

2 ut \% anthracene in hexadecane, 4.0 g bal charge, 30 min, hydrogen pressure given al ambient temperature. 
Table 3. Anthracene Hydrogenation Under Thermal and Catalytic Conditions

\begin{tabular}{|c|c|c|c|c|c|c|c|}
\hline \multicolumn{3}{|c|}{ Resetion Conditions } & \multicolumn{5}{|c|}{ Product Distribution (wt \%) } \\
\hline Catalyst & $\begin{array}{c}\text { Temperg- } \\
\text { ture } \\
\left({ }^{\circ} \mathrm{C}\right)\end{array}$ & $\begin{array}{c}\text { Pressure } \\
\text { (psi) }\end{array}$ & ANT & DIIA & TIIA & OHA & IIYD \% \\
\hline None & $\begin{array}{l}400 \\
350 \\
300\end{array}$ & $\begin{array}{l}500 \\
500 \\
500\end{array}$ & $\begin{array}{l}78.44 \pm 2.21 \\
100.0 \pm 0 \\
100.0 \pm 0\end{array}$ & $\begin{array}{c}21.56 \pm 2.21 \\
0 \pm 0 \\
0 \pm 0\end{array}$ & $\begin{array}{l}0 \pm 0 \\
0 \pm 0 \\
0 \pm 0\end{array}$ & $\begin{array}{l}0 \pm 0 \\
0 \pm 0 \\
n \pm 0\end{array}$ & $\begin{array}{l}3.1 \\
0 \\
0\end{array}$ \\
\hline $\begin{array}{l}\text { Molyvan L } \\
\text { (500 ppm) } \\
\text { Sulfur } \\
\end{array}$ & $\begin{array}{l}400 \\
350 \\
350 \\
\end{array}$ & $\begin{array}{l}500 \\
500 \\
500 \\
\end{array}$ & $\begin{array}{c}17.83 \pm 1.36 \\
9.41 \pm 2.84 \\
57.76 \pm 2.49\end{array}$ & $\begin{array}{l}67.09 \pm 0.53 \\
90.59 \pm 2.84 \\
42.24 \pm 2.49\end{array}$ & $\begin{array}{c}15.108 \pm 1.12 \\
0 \pm 0 \\
0 \pm 0\end{array}$ & $\begin{array}{l}0 \pm 0 \\
0 \pm 0 \\
0 \pm 0\end{array}$ & $\begin{array}{r}13.8 \\
12.9 \\
5.0\end{array}$ \\
\hline $\begin{array}{l}\text { Molyvan } 822 \\
(500 \mathrm{ppm}) \\
\text { Suifur }\end{array}$ & $\begin{array}{l}400 \\
350 \\
300 \\
\end{array}$ & $\begin{array}{l}500 \\
500 \\
500 \\
\end{array}$ & $\begin{array}{c}0 \pm 0 \\
0 \pm 0 \\
12.58 \pm 4.12\end{array}$ & $\begin{array}{l}27.66 \pm 1.33 \\
100.0 \pm 0 \\
87.42 \pm 4.12\end{array}$ & $\begin{array}{c}59.42 \pm 1.10 \\
0 \pm 0 \\
0 \pm 0\end{array}$ & $\begin{array}{c}12.92 \pm 1.09 \\
0 \pm 0 \\
0 \pm 0\end{array}$ & $\begin{array}{l}28.2 \\
14.3 \\
12.5\end{array}$ \\
\hline $\begin{array}{l}\text { Mo Naph } \\
\text { (500 ppmi) } \\
\text { Sulfur }\end{array}$ & $\begin{array}{l}400 \\
350 \\
350\end{array}$ & $\begin{array}{l}500 \\
500 \\
500\end{array}$ & $\begin{array}{c}0 \pm 0 \\
3.41 \pm 1.41 \\
42.74 \pm 3.34\end{array}$ & $\begin{array}{l}23.18 \pm 2.01 \\
96.59 \pm 1.41 \\
57.26 \pm 3.34\end{array}$ & $\begin{array}{c}60.4 \pm 1.76 \\
0 \pm 0 \\
0 \pm 0\end{array}$ & $\begin{array}{c}16.40 \pm 0.48 \\
0 \pm 0 \\
0 \pm 0\end{array}$ & $\begin{array}{r}29.8 \\
13.8 \\
8.1\end{array}$ \\
\hline
\end{tabular}

Reaction Conditions.

2 wt \% anthras ne in hexadecane, $30 \mathrm{~min}, 4 \mathrm{~g}$ total charge, 500 psi at ambient temperature.

Table 4. Yexahydruanthracene Hydrogenation Under Thermal and Catalytic Conditions

\begin{tabular}{|c|c|c|c|c|c|c|}
\hline \multicolumn{3}{|c|}{ Reaction Conditions } & \multicolumn{4}{|c|}{ Product Distribution (wt \%) } \\
\hline Catalyst & $\begin{array}{l}\text { Tempera- } \\
\text { ture }\left({ }^{\circ} \mathrm{C}\right)\end{array}$ & $\begin{array}{l}\text { Pressure } \\
\text { (psi) }\end{array}$ & ANT & DHA & IIIIA & OHA \\
\hline None & $\begin{array}{l}350 \\
300 \\
250\end{array}$ & $\begin{array}{l}500 \\
500 \\
500\end{array}$ & $\begin{array}{l}0 \pm 0 \\
0 \pm 0 \\
0 \pm 0\end{array}$ & $\begin{array}{c}41.55 \pm 2.07 \\
6.65 \pm 0.84 \\
0 \pm 0\end{array}$ & $\begin{array}{l}23.28 \pm 0.66 \\
70.83 \pm 3.19 \\
92.05 \pm 2.14\end{array}$ & $\begin{array}{l}35.17 \pm 1.53 \\
22.52 \pm 2.83 \\
7.95 \pm 2.14\end{array}$ \\
\hline $\begin{array}{l}\text { Molyvan L } \\
\text { (500 ppm) } \\
\text { Mo without } \\
\text { Sulfur }\end{array}$ & $\begin{array}{l}350 \\
300 \\
250\end{array}$ & $\begin{array}{l}500 \\
500 \\
500\end{array}$ & $\begin{array}{l}0 \pm 0 \\
0 \pm 0 \\
0 \pm 0\end{array}$ & $\begin{array}{l}0 \pm 0 \\
0 \pm 0 \\
0 \pm 0\end{array}$ & $\begin{array}{l}42.55 \pm 1.64 \\
39.02 \pm 1.07 \\
46.73 \pm 0.99\end{array}$ & $\begin{array}{l}57.45 \pm 1.64 \\
60.98 \pm 1.07 \\
53.27 \pm 0.99\end{array}$ \\
\hline $\begin{array}{l}\text { Molyvan } 822 \\
\text { (500 ppm) } \\
\text { Mo with } \\
\text { Sulfur }\end{array}$ & $\begin{array}{l}350 \\
300 \\
250\end{array}$ & $\begin{array}{l}500 \\
500 \\
500\end{array}$ & $\begin{array}{c}0 \pm 0 \\
0 \pm 0 \\
4.92 \pm 0.93\end{array}$ & $\begin{array}{l}11.15 \pm 0.51 \\
17.78 \pm 0.65 \\
7.56 \pm 0.84\end{array}$ & $\begin{array}{l}40.50 \pm 1.03 \\
38.19 \pm 0.62 \\
45.42 \pm 1.66\end{array}$ & $\begin{array}{l}48.35 \pm 1.30 \\
44.03 \pm 0.51 \\
40.10 \pm 1.49\end{array}$ \\
\hline $\begin{array}{l}\text { Ao Naph } \\
\text { (500 ppm) } \\
\text { Mo with } \\
\text { Sulfur }\end{array}$ & $\begin{array}{l}350 \\
300 \\
250\end{array}$ & $\begin{array}{l}500 \\
500 \\
500\end{array}$ & $\begin{array}{c}0 \pm 0 \\
0 \pm 0 \\
6.70 \pm 1.02\end{array}$ & $\begin{array}{l}13.86 \pm 0.84 \\
12.62 \pm 1.57 \\
9.81 \pm 0.88\end{array}$ & $\begin{array}{l}44.76 \pm 1.76 \\
40.26 \pm 0.83 \\
29.16 \pm 2.43\end{array}$ & $\begin{array}{l}41.38 \pm 0.96 \\
47.12 \pm 1.82 \\
54.33 \pm 0.65\end{array}$ \\
\hline
\end{tabular}

$\begin{array}{lll}\text { ANT }=\text { Anthracent } & \text { DHA }=\text { Dihydroantoracene } & \text { THA }=\text { Tetrahydroanthracent } \\ \text { OHA }=\text { Octahydroanthacene } & \text { HYD }=\text { Hydrogenation } & \text { Naph }=\text { Napheherate }\end{array}$

Reaction Conditions: 2 w1 \% hexahydroanthracene in hexadesane, 30 mis, a g lotal sharge, 500 psi at ambient lemperature. 

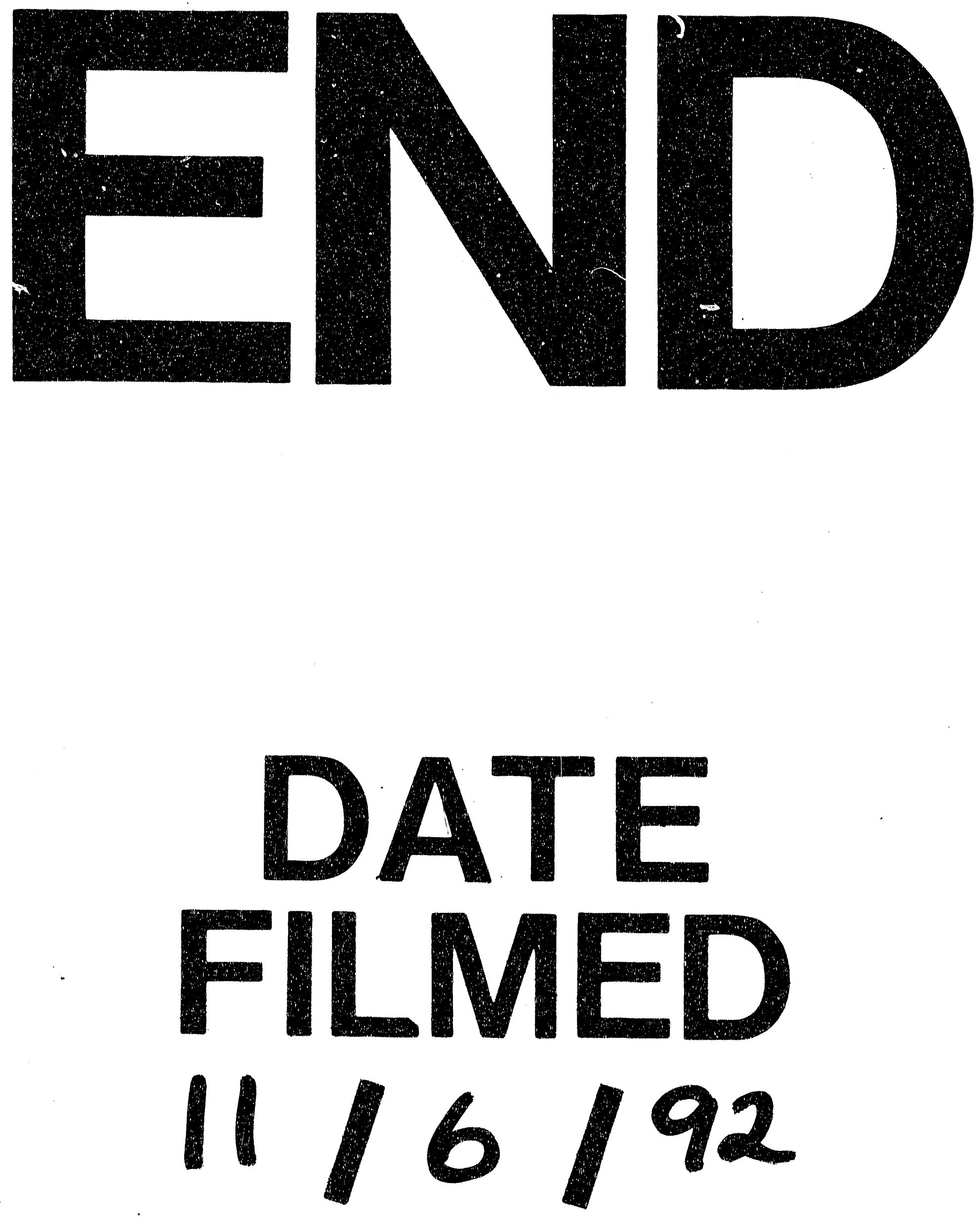

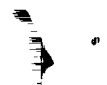


